\title{
Semi-sitting Position in Neurosurgery: A Review
}

\section{Posição semissentada em neurocirurgia: uma revisão}

\author{
Nícollas Nunes Rabelo ${ }^{1}$ Bruno Nascimento Bithencurt da Silva ${ }^{1}$ Christien Dannemberg Cunha ${ }^{1}$ \\ Igor de Souza Furtado ${ }^{1}$ Daniel Alves Branco Valli ${ }^{1}$ Luciano José Silveira Filho ${ }^{1}$ \\ Letícia Maria Prada Marchini ${ }^{1}$ Vitor Hugo Honorato Pereira ${ }^{1}$ George Santos dos Passos ${ }^{1}$ \\ Luiz Antônio Araujo Dias ${ }^{2}$ Luiz Antônio Araujo Dias Junior ${ }^{3}$ Koji Tanaka ${ }^{3}$ Fernando Eduardo Plastina ${ }^{3}$ \\ Neiffer Nunes Rabelo 4
}

${ }^{1}$ Neurosurgery Residency Program, Department of Neurosurgery,

Hospital Santa Casa, Ribeirão Preto, SP, Brazil

${ }^{2}$ Professor and Neurosurgeon, Department of Neurosurgery, Hospital

Address for correspondence Nícollas Nunes Rabelo, MD, Av. Antonio Santa Casa, Ribeirão Preto, SP, Brazil Diederichsen, n190, Ap 193, Jardim América, Ribeirão Preto, SP, Brazil

${ }^{3}$ Neurosurgeon, Department of Neurosurgery, Hospital Santa Casa, Ribeirão Preto, SP, Brazil

${ }^{4}$ Medical Student, Faculdade Atenas, Paracatu, Minas Gerais, Brazil 14020250 (e-mail: nicollasrabelo@hotmail.com).

Arq Bras Neurocir 2016;35:62-66.

\begin{abstract}
Specialists rarely perform neurosurgical procedures on patients in the semi-sitting position. This is due to several factors, most importantly, the perception of risks associated with this position and lack of practice in some services. Nevertheless, the benefit of this position is still the subject of controversy both in neurosurgery and neuroanesthesia. Our objective is to report on the benefits associated to its use for posterior fossa diseases and dorsal cervical spine procedures, through cases in the literature. We survey and analyze state-of -the art works that mention the semi-sitting position, based on searches in Pubmed, Scielo, Science Direct, and Lilacs. We found 46 original articles on the subject that we included in the review. This review demonstrates that the advantages for access in this position include gravitational drainage of venous blood and cerebrospinal fluid, easier surgical access to midline structures, as well as reduced cerebellar edema, surgery time and blood loss. This technique also allows ventilation with low pressure, less impairment of diaphragmatic motion, and better access to the tracheal tube. There are, however, some disadvantages, among which the most serious is paradoxical arterial embolism. We describe early detection methods of complications and discuss situations that can factor in

\section{Keywords}

- semi-sitting position

- surgery to the choice of position. In summary, a semi-sitting position is safe and effective in neurosurgical posterior fossa and the upper cervical spine, provided there is a joint effort between neurosurgeons and anesthesiologists in selecting patients and complying with the technical standards favorable to this technique.
\end{abstract}

received

April 20, 2014

accepted

August 28, 2015

published online

March 4, 2016
DOI http://dx.doi.org/

10.1055/s-0036-1572507. ISSN 0103-5355.
Copyright $(2016$ by Thieme Publicações License terms

Ltda, Rio de Janeiro, Brazil
()(1) $\Theta \circledast$ 


\section{Resumo}

\author{
Palavras-chave \\ - posição \\ semissentada \\ - cirurgia
}

Especialistas raramente realizam procedimentos neurocirúrgicos em pacientes em posição semi-sentada. Vários são os fatores, o mais importante, a percepção dos riscos associados a esta posição e falta de prática em alguns serviços. No entanto, o benefício desta posição ainda é objeto de controvérsia tanto em neurocirurgia e Neuroanestesia. Nosso objetivo é relatar os benefícios associados ao seu uso para doenças da fossa posterior e procedimentos da coluna cervical dorsal. Realizado um levantamento e analise do estado-da-arte dos documentos que mencionam a posição semi-sentada, com base em pesquisas em Pubmed, Scielo, Science Direct e Lilacs. Encontraram-se 46 artigos originais sobre o assunto que foram incluídos na revisão. Esta avaliação demonstra que as vantagens do acesso nesta posição incluem a drenagem gravitacional de sangue venoso e no líquido cefalorraquidiano, o acesso cirúrgico mais fácil para estruturas da linha média, bem como diminuição do edema cerebelar, tempo de cirurgia e perda de sangue. Esta técnica também permite a ventilação com pressão baixa, menor comprometimento da mobilidade diafragmática, e um melhor acesso ao tubo traqueal. Há, algumas desvantagens, entre as quais a mais grave é a embolia arterial paradoxal. Descreve-se métodos de detecção precoce de complicações e discutir situações que pode fator para a escolha de posição. Em resumo, esta posição é segura e eficaz em fossa posterior e da coluna cervical superior, desde que haja um esforço conjunto entre neurocirurgiões e anestesistas na seleção de pacientes e em conformidade com as normas técnicas favoráveis a esta técnica.

\section{Introduction}

The benefit of the semi-sitting position is still controversial in both neurosurgery and neuroanesthesia. Neurosurgical procedures in the semi-sitting position are rarely performed, mainly because of the perception of increased risk related to this position. While the patient in the vertical position offers a number of advantages to the neurosurgeon, there are challenges for the anesthetist. Many institutions frown upon the semi-position technique due to potential serious consequences, such as venous air embolism. The use of the semi-sitting position is apparently lowest in Japan. ${ }^{1,2}$

There are, however, indisputable advantages to the semisitting position for posterior fossa and dorsal cervical spine procedures. The sitting position allows gravitational drainage of venous blood and cerebrospinal fluid (CSF) and better guidance of surgical approaches to the midline structures, significantly reducing cerebellar edema, surgery time, and blood loss. These are key features that could contribute to a better outcome of patients in semi-sitting position. There are also several advantages to the anesthesiologist, such as the possibility of venting at lower pressure, less impairment of the diaphragm motion, and improved access to the tracheal tube. ${ }^{3-6}$

While there are specific complications associated with the semi-sitting position ${ }^{7-10}$, the use of the semi-sitting position should be based on an interdisciplinary dialogue between neurosurgeon and anesthesiologist.

\section{Discussion}

The use of the semi-sitting position remains controversial, despite its distinct advantages over the horizontal position.
Many institutions are reluctant to use it out of fear of serious complications, mainly air embolism and paradoxical embolism (PAE). Other concerns include venous gas embolus in the presence of a patent foramen ovale (PFO), hypotension, spinal cord syndrome, quadriplegia and pneumocephalus, damage to the peripheral nerve, quadriplegia, macroglossia, and paradoxical arterial embolism, which is the most serious complication. ${ }^{7-10}$

However, embolism during neurosurgery is not related exclusively to the sitting position and has often been reported in the prone and supine positions. While the advantages of the sitting position are well documented, the impact and relevance of long-term embolism has not been well investigated. Reports show there is less blood loss and better preservation of cranial nerve function in a semi-sitting position.

Embolism is not exclusively associated with the semisitting position. One study reported embolism in $10-17 \%$, also in of the craniotomy performed in the dorsal position. ${ }^{11}$ The overall incidence of gas embolism during surgery in semi-sitting position in cranial surgery is slightly higher, at $21 \%$. These results, which are gathered from the articles reviewed here, conform with previous studies, which report incidence of embolism ranging between 7 and $76 \%{ }^{3}$

It is important at this point to stress that the potential advantages of the sitting position are offset, in emergency cases (reduction of cerebellar swelling), even by the additional time spent by the surgical team positioning the patient, about 15-20 minutes, when compared to the upright position. In these cases, medical teams should consider alternative positioning techniques, such as semi-inclined.

The overall incidence of embolism in the sitting position is $39 \%$ for operations in the posterior fossa and $12 \%$ for 
cervical procedures. Detection rate also depended on the monitoring method, with transesophageal echocardiogram rate was $25.6 \%$, while with the esophageal Doppler it was $9.4 \% .^{12-16}$

Stendel et al performed transesophageal echocardiograms in neurosurgical patients in the lying and semi-sitting positions. Air embolism was observed in 35\% of cervical (foraminotomy) and $75 \%$ of posterior fossa operation cases. ${ }^{17}$

Some authors argue that the measurement of $\mathrm{ETCO}_{2}$ alone is an appropriate method for monitoring during the semisitting position. The incidence of embolism while monitoring for the fall in $\mathrm{ETCO}_{2}$ was $11 \%$ for cranial surgery and $6.8 \%$ for cervical spine surgery. ${ }^{9}$

Simply detecting embolism, however, does not necessarily mean the patient is at risk. It is just as important to investigate the sequelae associated with hemodynamic or respiratory embolism. ${ }^{14,18}$

Duke et al investigated the incidence of air embolism in a study of patients undergoing surgery for vestibular schwannoma in the sitting and supine positions. They found an incidence of $28 \%$ in the semi-seated position versus $5 \%$ in the supine position. Serious embolism with hypotension rates were $1.8 \%$ and $1.4 \%$, respectively, with no significant difference between the two groups. ${ }^{7}$

There are several other ways to detect venous air embolism, including transesophageal echocardiography, reduced end-tidal $\mathrm{CO}_{2}\left(\mathrm{ETCO}_{2}\right)$ pressure, precordial Doppler changes, increased pulmonary artery pressure in the catheter, and direct observation of clinical parameters. The transesophageal echocardiogram (TEE) is the most sensitive test, capable of detecting $0.02 \mathrm{~mL} / \mathrm{kg}$ of injected air bubbles, or 5 to 10 micrometers. However, it is expensive and impractical to keep trained professionals available continuously monitoring via TEE intraoperatively. Moreover, TEE may lead to complications such as esophageal bleeding, displacement of the endotracheal tube, and risk of glottis injury with prolonged use. ${ }^{15,17}$

Some measures to reduce the occurrence of embolism may actually induce an increase pulmonary artery pressure, which may lead to the occurrence of air embolism. Specifically, the positive end-expiratory pressure (PEEP), although it may reduce the occurrence of air embolism may also, through the increase in right atrial pressure, increase the risk of an intracardiac shunts from right to left, causing an increase pulmonary artery pressure. ${ }^{19,20}$

The influence of patient posture on the respiratory system has been studied in different situations. When healthy humans switch from the sitting to the supine posture, functional residual capacity reduces and breathing resistance increases. In other words, esophageal pressure values are slightly less negative when sitting compared to supine, but the transdiaphragmatic pressure remains the same. ${ }^{21,22}$

While such postural changes have limited relevance to healthy individuals, they may influence the breathing pattern and dyspnea in patients with severe chronic lung disease. The supine posture can increase intrinsic positive end-expiratory pressure, dynamic hyperinflation, airway resistance, expiratory flow limitation, or orthopnea in pa- tients with chronic obstructive pulmonary disease (COPD) or obesity. Conversely, some authors have reported relief of dyspnea for some patients with COPD non-ventilated while in the supine position. Nonetheless, the supine position can significantly reduce functional residual capacity in patients with phrenic or neuromuscular paralysis and, in mechanically ventilated patients, limitation of expiratory flow and PEEPi may increase. ${ }^{23-25}$

We found no significant change in respiratory effort between the sitting and supine positions in stable COPD patients under noninvasive ventilation, regardless of their seniority or obesity. In patients with prolonged or difficult weaning, respiratory muscle weakness is usually present. The effects of posture on these patients' breathing effort may be clinically relevant. Although a semi-sitting position in bed is often recommended for patients on mechanical ventilation because of the lower risk of microaspirations through the endotracheal tube, it is often difficult to maintain in clinical practice. $^{26,27}$

Respiratory effort significantly decreased in the semisitting position, more comfort, and less necessity of high PEEP compared with other positions. ${ }^{28}$

As for PEEPi and dyspnea, there were only minor changes across postures. The functional residual capacity is reduced by $20-30 \%$ when the patient goes from sitting to the supine posture. This effect relates to the increase in intrathoracic blood volume, the greater head position of the diaphragm, and the obstruction of small airways. The reduction in functional capacity leads to increasing resistance against the position to sit. ${ }^{29-31}$

In COPD patients, the supine position is associated with dyspnea, or orthopnea and expiratory flow. Limitation at rest manifests earlier more in the supine than in semi-sitting position. Many patients with COPD have more severe dyspnea in the supine position. In such cases, pulmonary hyperinflation, airway resistance, PEEP, and expiratory flow limitation may play a role in the genesis of orthopnea. In several patients with heart failure or obesity, airway resistance, increased PEEP, expiratory flow limitation, and orthopnea are also more prevalent in the supine position compared to semi-sitting. Patients with severe phrenic or neuromuscular paralysis experience a large reduction in functional residual capacity when supine. In mechanically ventilated adults with acute respiratory distress syndrome, the supine posture offers higher expiratory flow limitation and work-related PEEPi when compared to the semisitting. ${ }^{32-35}$

The semi-sitting position induces a smaller respiratory effort than the supine and sitting positions. Weaning patients experience a significant increase in respiratory load and muscle effort for breathing. Mechanical ventilation is meant to decrease this breathing effort to a level acceptable to the patient. Weaning failure often results from an imbalance between themechanical load and respiratorymuscle activity. Most studies evaluating changes in breathing effort according to position reported little to no differences. In healthy individuals, transdiaphragmatic pressures remained unchanged between supine, semi-sitting, and sitting. ${ }^{36}$ The 
same held true for elderly individuals in the semi-sitting and supine positions. In patients with stable COPD, transdiaphragmatic pressures were lower when sitting versus in supine. In obese individuals, there was no variation between average transdiaphragmatic pressures in the supine and sitting positions. While postural changes probably are not relevant to healthy and stable individuals, it may have relevance in patients with more severe respiratory difficulties. ${ }^{36-38}$

Several studies have indicated that many ICU patients are not positioned in a semi-reclined position. Although a $45^{\circ}$ position in bed is recommended for patients on mechanical ventilation, mainly because of decreased risk of microaspirations, reduce brain venous pressure, intracranial hypertension, this is often difficult to maintain in practice. ${ }^{39}$

\section{Conclusion}

As shown in the discussion above, the semi-sitting position is a safe and useful adjunct in neurosurgery of the posterior fossa and the upper cervical spine. Nonetheless, this requires team effort between dedicated neurosurgeons and anesthesiologists for a safe fit and seamless positioning. However, there are alternative ways to ensure adequate and safe positioning.

The semi-sitting position at a $45^{\circ}$ angle decreases the inspiratory effort, and is as comfortable or more for patients that suffer from difficult weaning in ventilation. Reports show that PEEP is moderately higher in the supine position, whereas the supine yields lower PEEPi values, but higher breathing effort, possibly because of a central command of the upper breathing. There is also the potential role of decreased chest wall compliance when sitting, as seen in paralyzed patients. These results are clinically relevant because they demonstrate that the semi-sitting position reduces PEEP and relieves respiratory muscles in difficult weaning situations.

\section{References}

1 Schaffranietz L, Grothe A, Olthoff D. [Use of the sitting position in neurosurgery. Results of a 1998 survey in Germany]. Anaesthesist 2000;49(4):269-274

2 Kida H, Nishikawa N, Matsunami K, Kawahito M, Ota M, Miyao S. [Sitting position in the neurosurgery: the results of a questionnaire sent to neurosurgeons of medical colleges]. Masui 2000; 49(5):566-569

3 Faberowski LW, Black S, Mickle JP. Incidence of venous air embolism during craniectomy for craniosynostosis repair. Anesthesiology 2000;92(1):20-23

4 Fathi AR, Eshtehardi P, Meier B. Patent foramen ovale and neurosurgery in sitting position: a systematic review. $\mathrm{Br} \mathrm{J}$ Anaesth 2009;102(5):588-596

5 Albin MS, Carroll RG, Maroon JC. Clinical considerations concerning detection of venous air embolism. Neurosurgery 1978;3(3): 380-384

6 Black S, Ockert DB, Oliver WC Jr, Cucchiara RF. Outcome following posterior fossa craniectomy in patients in the sitting or horizontal positions. Anesthesiology 1988;69(1):49-56

7 Duke DA, Lynch JJ, Harner SG, Faust RJ, Ebersold MJ. Venous air embolism in sitting and supine patients undergoing vestibular schwannoma resection. Neurosurgery 1998;42(6):1282-1286, discussion 1286-1287
8 Weingart JD, Brem H. Basic principles of cranial surgery for brain tumors. In: Winn HR, editor. Youmans neurological surgery. Philadelphia: Elsevier Saunders; 2011. p. 1261-6.

9 Harrison EA, Mackersie A, McEwan A, Facer E. The sitting position for neurosurgery in children: a review of 16 years' experience. $\mathrm{Br} \mathrm{J}$ Anaesth 2002;88(1):12-17

10 Orliaguet GA, Hanafi M, Meyer PG, et al. Is the sitting or the prone position best for surgery for posterior fossa tumours in children? Paediatr Anaesth 2001;11(5):541-547

11 Rath GP, Bithal PK, Chaturvedi A, Dash HH. Complications related to positioning in posterior fossa craniectomy. J Clin Neurosci 2007;14(6):520-525 10.1016/j.jocn.2006.02.010

12 Ganslandt O, Merkel A, Schmitt H, et al. The sitting position in neurosurgery: indications, complications and results. a single institution experience of 600 cases. Acta Neurochir (Wien) 2013;155(10):1887-1893

13 Leslie K, Hui R, Kaye AH. Venous air embolism and the sitting position: a case series. J Clin Neurosci 2006;13(4):419-422

14 Girard F, Ruel M, McKenty S, et al. Incidences of venous air embolism and patent foramen ovale among patients undergoing selective peripheral denervation in the sitting position. Neurosurgery 2003;53(2):316-319, discussion 319-320

15 Papadopoulos G, Kuhly P, Brock M, Rudolph KH, Link J, Eyrich K. Venous and paradoxical air embolism in the sitting position. A prospective study with transoesophageal echocardiography. Acta Neurochir (Wien) 1994;126(2-4):140-143

16 Michenfelder JD, Miller RH, Gronert GA. Evaluation of an ultrasonic device (Doppler) for the diagnosis of venous air embolism. Anesthesiology 1972;36(2):164-167

17 Stendel R, Gramm HJ, Schröder K, Lober C, Brock M. Transcranial Doppler ultrasonography as a screening technique for detection of a patent foramen ovale before surgery in the sitting position. Anesthesiology 2000;93(4):971-975

18 Lobato EB, Black S, De Soto H. Venous air embolism and selective denervation for torticollis. Anesth Analg 1997;84(3):551-553

19 Palmon SC, Moore LE, Lundberg J, Toung T. Venous air embolism: a review. J Clin Anesth 1997;9(3):251-257

20 Albin MS. Letter to editor: the paradox of paradoxic air embolism - PEEP, valsalva, and patent foramen ovale, should the sitting position be abandoned? Anesthesiology 1984;61:222-3

21 Druz WS, Sharp JT. Activity of respiratory muscles in upright and recumbent humans. J Appl Physiol 1981;51(6):1552-1561

22 Druz WS, Sharp JT. Electrical and mechanical activity of the diaphragm accompanying body position in severe chronic obstructive pulmonary disease. Am Rev Respir Dis 1982;125(3): 275-280

23 Mier-Jedrzejowicz A, Brophy C, Moxham J, Green M. Assessment of diaphragm weakness. Am Rev Respir Dis 1988;137(4):877-883

24 Fromageot C, Lofaso F, Annane D, et al. Supine fall in lung volumes in the assessment of diaphragmatic weakness in neuromuscular disorders. Arch Phys Med Rehabil 2001;82(1):123-128

25 Valta P, Corbeil C, Lavoie A, et al. Detection of expiratory flow limitation during mechanical ventilation. Am J Respir Crit Care Med 1994;150(5 Pt 1):1311-1317

26 Tablan OC, Anderson LJ, Besser R, Bridges C, Hajjeh R; CDC; Healthcare Infection Control Practices Advisory Committee. Guidelines for preventing health-care-associated pneumonia, 2003: recommendations of $C D C$ and the Healthcare Infection Control Practices Advisory Committee. MMWR Recomm Rep 2004;53(RR-3):1-36

27 Drakulovic MB, Torres A, Bauer TT, Nicolas JM, Nogué S, Ferrer M. Supine body position as a risk factor for nosocomial pneumonia in mechanically ventilated patients: a randomised trial. Lancet 1999;354(9193):1851-1858

28 van Nieuwenhoven CA, Vandenbroucke-Grauls C, van Tiel FH, et al. Feasibility and effects of the semirecumbent position to prevent ventilator-associated pneumonia: a randomized study. Crit Care Med 2006;34(2):396-402 
29 Agostoni E, Hyatt RE. (1986) Static behaviour of the respiratory system. In: Handbook of physiology, sect 3, vol III, part 1, chap 9. American Physiological Society, Washington, pp 113-130

30 Behrakis PK, Baydur A, Jaeger MJ, Milic-Emili J. Lung mechanics in sitting and horizontal body positions. Chest 1983;83(4):643-646

31 Baydur A, Sassoon CS, Carlson M. Measurement of lung mechanics at different lung volumes and esophageal levels in normal subjects: effect of posture change. Lung 1996;174(3):139-151

32 Knowles JH, Hong SK, Rahn H. Possible errors using esophageal balloon in determination of pressure- volume characteristics of the lung and thoracic cage. J Appl Physiol 1959;14:525-530

33 Reeve BK, Cook DJ. Semi- recumbency amoung mechanically ventilated ICU patients: a multicenter observational study. Clin Intensive Care 1999;10:241-244

34 Grap MJ, Munro CL, Hummel RS III, Elswick RK Jr, McKinney JL, Sessler CN. Effect of backrest elevation on the development of ventilator-associated pneumonia. Am J Crit Care 2005;14(4): 325-332, quiz 333
35 Servillo G, Svantesson C, Beydon L, et al. Pressure-volume curves in acute respiratory failure: automated low flow inflation versus occlusion. Am J Respir Crit Care Med 1997;155(5): 1629-1636

36 Maggiore SM, Jonson B, Richard JC, Jaber S, Lemaire F, Brochard L. Alveolar derecruitment at decremental positive end-expiratory pressure levels in acute lung injury: comparison with the lower inflection point, oxygenation, and compliance. Am J Respir Crit Care Med 2001;164(5):795-801

37 Truwit JD, Marini JJ. Evaluation of thoracic mechanics in the ventilated patient. Part II: applied mechanics. J Crit Care 1988; 3:199-213

38 Burns SM, Egloff MB, Ryan B, Carpenter R, Burns JE. Effect of body position on spontaneous respiratory rate and tidal volume in patients with obesity, abdominal distension and ascites. Am J Crit Care 1994;3(2):102-106

39 Boles JM, Bion J, Connors A, et al. Weaning from mechanical ventilation. Eur Respir J 2007;29(5):1033-1056 